\title{
Improved Adherence to ART in Children - Orphans with AIDS Results in the Decreasing Occurrence of Tuberculosis (Research paper)
}

G. Mikolasova (Gerti Mikolasova)1,2, S. Seta (Song Seta)', H. Hoin (Hong Hoin)', J. Otrubova (Jana Otrubova) 1,2, J. Benca (Juraj Benca) 1,2, M. Bartkovjak (Marian Bartkovjak) 1,2, F. Hvizdak (Frantisek Hvizdak)1,2, B. Durcova (Barbora Durcova) 1,2, M. Olah (Michal Olah)', A. Beresova (Anna Beresova),', P. A. Haj (Peri Ali Haj), ${ }^{1,2}$

${ }^{1}$ St. Maximilian Kolbe House of Hope, Phnom Penh, Kingdom of Cambodia

2 Tropical MSc. PhD. Program SEU, St. Lesley College Nove Zamky, Slovakia and Kuala Lumpur Malaysia

\section{E-mail address:}

tropicteam@gmail.com

\section{Reprint address:}

Song Seta

House of Hope

Phnom Penh

Cambodia

Source: Clinical Social Work and Health Intervention

Pages: $81-83$
Volume: 9

Cited references: 4

Issue: 4

\section{Reviewers:}

Andrea Shahum

UNC Chapel Hill, NC, USA

\section{Key words:}

Pediatric AIDS. Tuberculosis. HIV Treatment Adherence.

\section{Publisher:}

International Society of Applied Preventive Medicine i-gap

CSWHI 2018; 9(4): 81 - 83; D0I 10.22359/cswhi_9_4_14 @ 2018 Clinical Social Work and Health Intervention

\section{Abstract:}

Tuberculosis (TB) is one of the most frequent opportunistic infections in children with HIV in South-East Asia (SEA) together with candidiasis 
and Herpes Zoster (HZV). After immunity re-constitution due to antiretroviral therapy (ART), occurrence of OI in AIDS decreased rapidly, including TB.

\section{Introduction}

Orphans with AIDS and their improved adherence to therapy and decreasing the incidence of TB in a full board Pediatric HIV Facility in Cambodia have been observed for the last 15 years. Opportunistic infections (OI) are the major cause of mortality in children and adults with AIDS. Tuberculosis (TB) is one of the most frequent OI in children with HIV in South-East Asia (SEA) together with candidiasis and Herpes Zoster (HZV). After immunity constitution due to antiretroviral therapy (ART) occurrence of OI in AIDS decreased rapidly, including TB. After 15 years of directly observed (DO) ARV therapy, only 1 case of TB among 40 children with AIDS occurred.

\section{Patients and Methods}

Sputum samples/blood from 31 children in an orphanage sheltering children with AIDS in Phnom Penh were undergoing Gene X-pert test for presence of latent TB infection. Gene X-pert was approved by $\mathrm{WHO}$ as a PCR point-of-care testing method for detection of MTB within 1 hour instead of 30 - 60 days. All children received ART for 2 - 12 years.

\section{Results}

Despite 10 children having a history of TB for the past 12 years, due to highly active antiretroviral therapy (HAART) all TB cases were cured after 6-0 months of combination of RIF+INH+PZA, Gene X-pert test was negative in all 31 children despite 4 having a recurrent history of TB within 6 months, all were receiving anti-TB therapy (3-4).
Table 1: Decrease of TB among orphans with AIDS receiving ART for 2 - 12 years.

\begin{tabular}{|l|c|c|}
\hline & $\begin{array}{r}\text { With } \\
\text { AIDS }\end{array}$ & $\begin{array}{c}\text { Without } \\
\text { AIDS }\end{array}$ \\
\hline Number of Children & 31 & 4 \\
\hline Past History of TB & 10 & 0 \\
\hline Current History of TB & 4 & 0 \\
\hline Radiology Positive & 4 & 0 \\
\hline Gene-Xpert Positive & 0 & 0 \\
\hline
\end{tabular}

\section{Conclusion}

Orphanages as a closed environment with community programs are protective against non-adherence to ARV in children. Proper intake of ART prevents from major OI including TBC, what has been documented by a new PCR based quick point of care test X-pert, which is also a method reliable in tropical and remoted settings.

\section{References:}

1. HAJJ P A, DUDOVA Z, KRCMERY V, TOMANEK P, HRINDOVA T, POLONOVA J, ZOLLER K, DORKO D, DURECOVA B, BARTOSOVIC I, SPANIK S, BUJDOVA N, RIDOSKO J, MELLINGHOFF F (2017) Spectrum of Bacterial Isolates and Diagnoses in Physiotherapy and Rehabilitation Facility before and after Armed Conflict in Iraq (Research Note). In Clinical Social Work and Health Intervention. Vienna: GAP, 2017. No. 3. Vol. 8. 15 - 17 p. DOI 10.22359/cswhi_8_3_02. ISSN 2222-386X.

2. HOIN L, PALUN M, GALLO A, SLADECKOVA V, DURCOVA B, BENCA J et al (2018) Orphan Status may be Protective Factor Against Severe Toxicity of HIV Therapy in Children from Resource-limited 
Settings (case report). Clinical Social Work and Health Intervention, 9(3), 71-73. doi:10.22359/cswhi_9_3_10.

3. SHAHUM A, KALAVSKA A, CHABADOVA M, KALAVSKY E, BENCA J, MRAZOVA M,... KRCMERY V (2017) Quality of Life, Risk Factors and Mortality in Children with HIV/AIDS on 2nd Line Treatment, Slow Progressors and Late Presenters in Cambodian Orphanage. Clinical
Social Work and Health Intervention, 8(2), 7-12. doi:10.22359/cswhi_8_2_01.

4. SHAHUM A, SLADECKOVA V, BENCA J, KRCMERY V, STERNNBERG N, DUDOVA Z, . . MUSS C (2017). Reversibility of Antibiotic Resistance in an Orphanage of Children with AIDS in Cambodia. Clinical Social Work and Health Intervention, 8(1), 42-45. doi:10.22359/cswhi_8_1_09. 